\title{
Contribution of Agroforestry Plants to Farmers' Income in Nglanggeran Agricultural Technology Park
}

\author{
Wahyu Adhi Saputro ${ }^{1}$, Singgih Purnomo ${ }^{2}$, and Ika Rahmawati ${ }^{1}$ \\ ${ }^{1}$ Agribusiness Study Program, Faculty of Science and Technology, Duta Bangsa University Surakarta, J1.Pinang 47, Cemani, \\ Grogol, Sukoharjo, Central Java, Indonesia \\ ${ }^{2}$ Management Study Program, Faculty of Law and Business, Duta Bangsa University Surakarta, Jl.Pinang 47, Cemani, Grogol, \\ Sukoharjo, Central Java, Indonesia
}

\begin{abstract}
Agroforestry cultivation is very often practiced in Indonesia. In particular, combining cocoa plantations with several other types of plants such as woody plants, bananas and other plants. This is also done by farmers in the Nglanggeran Agricultural Technology Park. Cultivating agroforestry crops has many advantages, one of which is increasing profits. This study aims to determine the composition of agroforestry patterned crops that provide the highest income and welfare levels for farmers. This research uses analytical descriptive method. The sample used is 60 farmers who cultivate the main crop of cocoa in Nglanggeran Village. Based on the research results, it can be seen that type 6 criteria provides more benefits by combining cocoa with Mahogany, sengon, guava crystals, and durian plants. These criteria have an Average income / household / year of IDR 18,120,430. The highest contribution is in Criterion IV, followed by Criterion VI, then followed by Criteria I, II, V and III. The highest contribution is criterion 4 with a contribution to farmers' income of $60.32 \%$.
\end{abstract}

Key words: Agroforestry, Cocoa, Contribution, Farmers Nglanggeran,

\section{Introduction}

One of the non-oil and gas foreign exchange earners obtained by Indonesia comes from cocoa. This commodity provides its own role and has an important meaning for the socio-economic aspects. Large employment opportunities are created for residents in Indonesia as farmers and make it the main income for the family, especially for areas in cocoa production centers such as in the Nglanggeran Technology Park. It also has other benefits such as preserving the productivity of natural resources [1]. One of the agricultural countries is Indonesia, with most of its population working as farmers. The agricultural sector in Indonesia has become the foundation because there is a lot of fertile land plus a tropical climate which makes Indonesia have perfect soil [2]. Indonesia is one country that has a fairly good cocoa production. As many as 1.6 million farming families in Indonesia have their main source of income from cocoa cultivation [3]. The avera ge farmer who cultivates cocoa has about 25.7 years of experience [4]. This indicates that cocoa farmers are not new farmers who have minimalexperience in cocoa cultivation [5].

Nature tourism is the best-selling tour and there a re interesting elements to be visited by some people. Treatments of natural nuances in tourist a ttractions encoura ge this location to become a regional icon which is of course supported by good access as well. This is the case in Nglanggeran which has natural tourism spots and most of the population makes a living as farmers who cultivate cocoa as the main commodity [6].

Agroforestry is a land use system that is both economically and environmentally sustainable. In this system, diversity of plants is created in an area of land so that it will reduce the risk of failure and protect the soil from erosio $n$ 
and reduce the use of crop residues due to recycling of crop residues. Residents in Nglanggeran who are members of the Agricultural Technology Park cultivate the staple crop of cocoa as an agroforestry crop that can generate income for farmers. The Agricultural Technology Park which is coordinated by the Agricultural Technology Study Center supported by the Regional Government and related local institutions is a vehicle for the application of direct technological innovation in the field of community-owned agricultural land, with intensive assistance from refiners and farmers so that farmers can be skilled in applying modern technology. Provincial and Regency/Municipal Governments that have authority in terms of budgeting, development planning, organization al structuring, and human resources. So indirectly the members of the Agricultural Technology Park are farmers, researchers, extension workers and the government. Of course, the cacao plant is also intercropped with several other plants. The contribution of agricultural products, especially those from cocoa, is very important for farmers in Nglanggeran Agricultural Technology Park [7]. An increase in cocoa production will certainly be proportional to the increased income of farmers. The main factors contributing to this increase were the price of output products, the availability of fertilizers, pesticides, and an increase in marketing channels [8]. Some countries with the highest cocoa production are able to produce 3 tonnes per hectare per leaf [9]. Of course, this must also be followed by the use of the best cocoa varieties [10]. This study aims to determine the contribution of agroforestry plants to farmers' income in the Nglanggeran Agricultural Technology Park

\section{Material and methods}

This study uses a descriptive analytic method based on primary data. Primary data was obtained by interviewing farmers in the Nglanggeran agricultural technology park. The number of interviewed farmers was 60 people with qualifications of farmers who planted agroforestry crops with the main cacao crop. Analysis of the data used in this study was obtained quantitatively to get the income of farmers who use agroforestry plants in the form of cocoa. The totalincome of farmers per year is obtained from the total revenue per year minus the total production costs per year. Then the income per crop composition is compared to determine the highest income for the farmer. The analytical method used to answer the contribution of agroforestry farming income to farmerhousehold income is carried out by using calculations, the percentage formulation of the contribution calculation is as follows:

Information :

$$
\mathrm{Z}=\mathrm{A} / \mathrm{B} \times 100 \%
$$

$\mathrm{Z}=$ Contribution of Agroforesty Income (\%)

$\mathrm{A}=$ Cocoa Farming Income $(\mathrm{Rp})$

$\mathrm{B}=$ household income of the farmer (apart from farming and other family members' income)

Before calculating the a mount of contribution, it would be better to know in advance about the revenue and income of each farmer. Farming revenue is the multiplication between the production obtained and the selling price. Mathematically formulated as follows:

Information :

$$
\mathrm{TR}=\mathrm{Y} \cdot \mathrm{Py}
$$

$\mathrm{TR}=$ total revenue

$\mathrm{Y}=$ production obtained from a farm

Py $=$ production price

After knowing the income of each farmer, then proceed to calculate the income of the farmer. Income analysis can be used to find out this. Steps to calculate income can use a way of reducing the revenue received by farmers with the total costs that have been incurred by farmers in one production process [7].

\section{Results and discussions}

The agricultural technology park located in Nglanggeran Village is a program carried out by the Ministry of Agriculture in various parties. The program is given to farmers who live in Nglanggeran Village by integrating cocoa with eta wa goat cultivation. The fact is that farmers in the Nglanggeran Agricultural Technology Park have cultivated cocoa from generation to generation and there are even some rocks that are given to increa se cocoa production in that location. Farmers in the village certainly do not plant in monoculture, but combine cocoa with various kinds of plants 
that are considered to be able to produce and provide additional benefits for farmers. That way, cocoa cultivation is still the main focus in the obtaining stage for farmers who are in the Nglanggera n Agricultural Technology Park. Table 1 explains what plants are planted by farmers a long with the number and a verage age of these plants.

Table 1. Types Of Plants Cultivated Based On Age In Nglanggeran Agricultural Technology Park

\begin{tabular}{llcc}
\hline \multicolumn{1}{c}{ Types of Plants } & \multicolumn{1}{c}{ Latin Name } & $\begin{array}{c}\text { Average number of } \\
\text { plants / Ha }\end{array}$ & Average Plant Age \\
\hline Cocoa & Theobroma cacao & 193 & 12 \\
Mahogany & Mahagony sp. & 85 & 4 \\
Sengon & Paraserienthes & 85 & 4 \\
& Falcataria & & \\
Durian & Durio zibethinus & 20 & 15 \\
Rambutan & Nephelium lappaceum & 25 & 10 \\
Petai & Parkia spesiosa & 15 & 10 \\
Guava & Psidium Guajava & 25 & 6 \\
\hline
\end{tabular}

Table 1 indicates that farmers in Nglanggeran Village plant several crop commodities in their planted areas such as cocoa, mahogany, sengon, durian, rambutan, farmers and guava. In a unit of 1 hectare of cultivated area, there are 193 caca o plants. The a vera ge farmer in Nglanggeran Agricultural Technology Park is 3 to 4 meters apart. The a verage age of cocoa grown by farmers is around 12 years. Of course, this is still in a productive and good age. However, in reality, the production side has not been maximized because farmers have side jobs as managers of tourist sites in Nglanggeran. The timber plants cultivated by farmers are mahogany and sengon. On a verage, there are 85 trees planted in an area of 1 hectare. When viewed from the age of the trees, they cannot be harvested so that they cannot be used as additionalbenefits for farmer households. There are also fruit plants that are cultivated by farmers for profit, such as durian, with an average of 20 trees per hectare with an average age of 15 years. Rambutan and guava plants with an avera ge number of plants per hectare of 25 plants and an a verage age of 10 years of rambutan plants and 6 y ears of gua va plants. There are also petai plants cultivated by farmers with an a verage of 15 trees perhectare and an a verage age of 10 years. Table 2 describes the composition and combination of cocoa plants cultivated by Nglanggeran Technological Park farmers. 
Table 2. Composition of agroforestry crops in Nglanggeran Agricultural Technology Park

\begin{tabular}{|c|c|c|c|c|}
\hline $\begin{array}{l}\text { Compotition Of Plant } \\
\text { Types }\end{array}$ & Types of Main Plants & Types of Side Plants & Number Households & Percentage \\
\hline $\mathrm{I}$ & Cocoa & $\begin{array}{l}\text { Mahogany, Sengon, } \\
\text { Durian }\end{array}$ & 3 & 5 \\
\hline II & Cocoa & Mahogany, Sengon & 39 & 65 \\
\hline III & Cocoa & Rambutan & 3 & 5 \\
\hline IV & Cocoa & petai & 6 & 10 \\
\hline V & Cocoa & $\begin{array}{l}\text { Mahogany, Sengon, } \\
\text { Guava Crystals }\end{array}$ & 6 & 10 \\
\hline VI & Cocoa & $\begin{array}{l}\text { Mahogany, sengon, } \\
\text { jambu kristal, Guava } \\
\text { Crystals, durian }\end{array}$ & 3 & 5 \\
\hline Total & & & 60 & 100 \\
\hline
\end{tabular}

Based on table 2, it can be seen that the majority of the population in the Nglanggeran Agricultural Technology Park does not only cultivate cocoa alone in its plant a rea but by combining it with several cultivable plants. Table 1 explains that there are five categories of intercropping that can be done with the main crop, namely cocoa. Ba sically, cocoa can be combined with several types of plants, for example, farmers and timber plants. Table 2 explains that the cocoa that is owned and cultivated by farmers in the Nglanggeran Agricultural Technology Park combines with other crops such as mahogany, sengon, farmers, rambutan, guava, and durian. The majority or most of the farmers often combine or intercross the cultivation of cocoa with timber plants in the form of mahogany and sengon. This is because in addition to farmers getting production from cocoa they can also increase other income from the production of their by-products so that farmers hope to have sufficient income. From some of these categories, it can be seen which category has the highest income as seen in table 3.

Table 3. Income composition of agroforestry crops in Nglanggeran Agricultural Technology Park

\begin{tabular}{lrrrr}
\hline $\begin{array}{l}\text { Compotition Of Plant } \\
\text { Types }\end{array}$ & $\begin{array}{c}\text { Total Revenue / Year } \\
\text { (Rp.Thousand) }\end{array}$ & $\begin{array}{c}\text { Total Production Cost } \\
\text { / Year (Rp.Thousand) }\end{array}$ & $\begin{array}{c}\text { Total Income / Year } \\
\text { (Rp.Thousand) }\end{array}$ & $\begin{array}{c}\text { Average income / } \\
\text { household / year } \\
\text { (Rp.Thousand) }\end{array}$ \\
\hline I & 40,050 & $1,575.00$ & $38,475.00$ & $12,825.00$ \\
II & 458,640 & $13,338.00$ & $445,302.00$ & $11,418.00$ \\
III & 29,100 & 981.75 & $28,118.25$ & $9,372.75$ \\
IV & 75,960 & $1,902.00$ & $74,058.00$ & $12,343.00$ \\
V & 67,230 & $4,114.80$ & $63,115.20$ & $10,519.20$ \\
VI & 56,520 & $2,158.71$ & $54,361.29$ & $18,120.43$ \\
\hline
\end{tabular}

Table 3 explains which categories of intercropping types generate relatively high income compared to others. Table 3 implicitly shows that category VI has the highest income. In this category, farmers cultivate cocoa with timber pla nts such as mahogany and sengon plus high yielding value crops such as durian and rambutan so that farmers' income does not only come from cocoa but also comes from other a groforestry crops.

Table 4. Contribution Revenue of agroforestry crops in Nglanggeran Agricultural Technology Park

\begin{tabular}{lcrrr}
\hline $\begin{array}{l}\text { Compotition Of Plant } \\
\text { Types }\end{array}$ & $\begin{array}{c}\text { Average farm income / } \\
\text { household / year } \\
\text { (Rp.Thousand) }\end{array}$ & $\begin{array}{c}\text { Average farm area } \\
\text { income / household / } \\
\text { year (Rp.Thousand) }\end{array}$ & $\begin{array}{c}\text { Average total income / } \\
\text { year / household / year } \\
\text { (Rp.Thousand) }\end{array}$ & $\begin{array}{c}\text { Farmers' Income } \\
\text { Contribution to Total } \\
\text { Income }(\%)\end{array}$ \\
\hline I & $12,825.00$ & 12,160 & $24,985.00$ & 51.33 \\
II & $11,418.00$ & 11,400 & $22,818.00$ & 50.04 \\
III & $9,372.75$ & 12,500 & $21,872.75$ & 42.85 \\
IV & $12,343.00$ & 8,120 & $20,463.00$ & 60.32 \\
V & $10,519.20$ & 11,720 & $22,239.20$ & 47.30 \\
VI & $18,120.43$ & 13,020 & $31,140.43$ & 58.19 \\
\hline
\end{tabular}

Source: Primary data analysis 
The results of the study based on those listed in table 4, it is known that criterion 4 is the criterion with the highest contribution, then followed by criterion 6 . Criterion 4 has a contribution value of $60.32 \%$ while criterion 6 has a contribution of $58.19 \%$. There are certainly many things that affect the amount of contribution value each criterion has. The first thing that has an influence is the selling price because income depends on the selling price of the cultivated plant commodity. Farmers' cocoa in the Nglanggeran Agriculture technology park is indeed sold by farmers in several forms, such as fresh cocoa and fermented cocoa. Of course, the selling price of the two forms of cocoa is different. Fermented cocoa has a higher price than fresh cocoa yields. The second thing that affects the contribution and income of farmers is the cost of a gricultural production. The more companion plants and the more cocoa that is planted, of course, the costs are quite high, especially for the cost of purchasing fertilizers and the cost of plant maintenance. The third thing that affects the contribution value of a groforestry plants in the Nglanggeran Agricultural Technology Park is the income of farmers or members of farming households who work outside of a griculture. Many farmers have side activities such as participating in the work of guarding the Nglangggeran Ancient Volcano tourism and Nglangggeran Embung. However, if you look at table 4, it is true that the contribution of a groforestry plants has a large impact on totalhousehold income because all criteria have a contribution value of more than $40 \%$.

\section{Conclusions}

Based on this description, it can be said that most of the farmers in the Nglanggeran Agricultural Technology Park cultivate cocoa a groforestry plants that are combined with other plants. Of course, the selection of plants is a plant with a fairly high selling value such as mahogany and sengon. There are 6 criteria for the cultivation of cocoa agroforestry carried out by Nglanggeran farmers. Criterion VI is the criterion that generates the highest income for farmers. Criterion VI composes the cultivation of cocoa plants with several side plants such as mahogany, sengon, durian, and rambutan. The choice of side plants is not without reason but to seek additionalincome from side crops so that plants that have yields with high selling value are chosen. These criteria have an Avera ge income / household / year of IDR 18,120,430. The highest contribution is in Criterion IV, followed by Criterion VI, then followed by Criteria I, II, V and III.

\section{References}

1. Ayun, Q. WA Saputro, Fidayani, Y. Journal Science Innovation and Technology (SINTECH). 1,1:1 -6(2020). [in Bahasa Indonesia].https://ojs.udb.ac.id/index.php/SINTECH/article/view/855

2. Ayun, Q. Kurniawan, S. WA Sa putro. VIGOR: Jurnal Ilmu Pertanian Tropika dan Subtropika. 5,2:38-44(2020). http://dx.doi.org/10.31002/vigor.v5i2.3040

3. WA Saputro. Helbawanti, O. Paradigma Agribisnis. 3,1:7-15(2020). [in Bahasa Indonesia]. http://dx.doi.org/10.33603/jpa.v3i1.3942

4. Ebewore, S. O., Egho, E. O., \& Enujeke, E. C. (2013). Asian Journal of Agricultural Sciences, 5,1: 6-10 (2013). http://dx.doi.org/10.19026/ajas.5.2327

5. Oyediran, W. O., Omoare, A. M., Ajagbe, B. O., \& Sofowora, O. O. World Journal of Biology and Medical Sciences, 1,3:108-117(2014). http://www.sasjournals.com/july sept2014/10...108-117.pdf

6. Solichin, A. DAR, Amalia. Katniaty, L. T. Wisudawati. E Sulistyowati. WA Saputro. Journal Economics and Management(JECMA). 1,2:1-9(2021). [in Bahasa Indonesia]. https://doi.org/10.46772/jecma.v 1i02.355

7. Saputro, W.A. and W. Sariningsih. Journal SEPA, 16,2:208-217(2020). [in Bahasa Indonesia]. https://doi.org/10.20961/sepa.v16i2.35825

8. Gockowski, J., Serpong, B., Dziwornu. Journal of International Agriculture, 50,2:175-200(2011). https://doi.org/10.22004/ag.econ.155531

9. Yapo, K. D., Ouffoue, S. K., N'guessan, B. R., Okpekon, T. A., Dade, J., Say, M., and Kouakou, T. H. Journalde la Société Ouest-Africaine de Chimie, 37:56-64 (2014).

10.Wessel, M., and Quist-Wessel, P.F. NJAS-Wageningen Journal of Life Sciences, 74:1-7(2015). https://doi.org/10.1016/j.njas.2015.09.001 